\title{
Semiquantitative Assay of Erythrocyte Glucose-6-phosphate Dehydrogenase Activity by a New Modification of the MoTULSKY Test
}

TöNZ and BETKE ${ }^{1,2}$ modified in 1961 the original screening test described by MorulskY ${ }^{3}$ into a semiquantitative method for the evaluation of red cell glucose6-phosphate dehydrogenase. The modification consists of the decolouration of methylene blue instead of brillantkresyl blue, the use of a standardized light source stimulating NADP reduction and a CO persufflation producing the anaerobic condition. By this technic valuable semiquantitative results are obtained and a markedly decreased or increased enzyme activity is easily detected ${ }^{4}$. In clinical practice the method can therefore be used for the evaluation of an increased enzyme activity, i.e. of a reduced mean cell age as well. However, the need of a CO source constitutes the disadvantage of the method in hospital laboratories as the current gas is mostly detoxified. We thus investigated the accuracy of the same test.

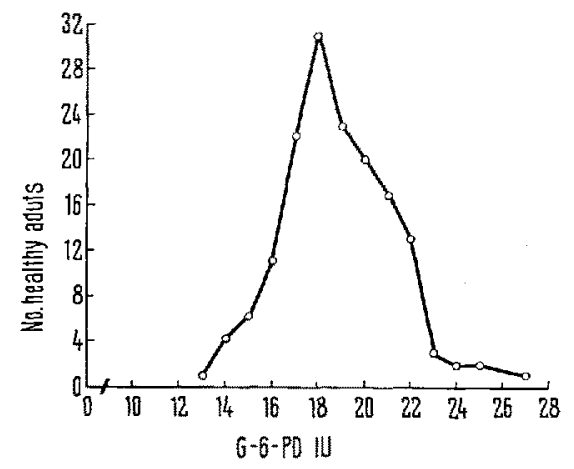

Fig. 1. Red cell G-6.PD activity in 150 hematologically healthy adults measured by the modified dye test.

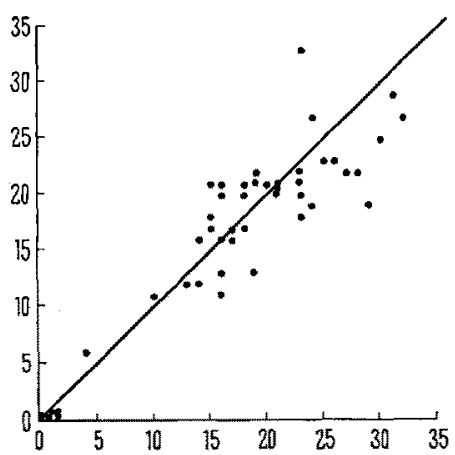

Fig. 2. Comparison of the red cell G-6-PD values measured by the modified dye test (ordinate) and exact spectrophotometrical determination of the NADP reduction (abscissa) in 45 persons with different enzyme activity. replacing the $C O$ persufflation by a supernatant layer of liquid paraffin as originally described by Motulsky. A more concentrated hemolysate is used and an empirical coefficient allows the enzyme activity to be calculated in IU. The less strict anaerobic condition prolongs the reaction time from 6-40 min only to 15-45 min without influencing the accuracy of the results.

Method. $0.1 \mathrm{ml}$ capillary blood or citrated venous blood is hemolysed in $5 \mathrm{ml}$ destilled water. The hemoglobin concentration is roughly adjusted into the range of 200 to $350 \mathrm{mg} \%$ by adding water and measured by the hemiglobincyanide method. In a test tube of $1 \mathrm{~cm}$ diameter the following mixture is prepared: $1.0 \mathrm{ml}$ hemolysate $+0,2 \mathrm{ml}$ Tris buffer $\mathrm{pH} 7.60 .74 M+0.1 \mathrm{ml} 1 \mathrm{~g} \% \mathrm{G}-6-\mathrm{P}-\mathrm{Na}$ solution $(10 \cdot \mathrm{mg} / \mathrm{ml})+0.1 \mathrm{ml} 50 \mathrm{mg} \%$ NADP solution $(0.5 \mathrm{mg} / \mathrm{ml})+0.25 \mathrm{ml}$ methylene blue solution $10^{-3} \mathrm{M}$ $(0.374 \mathrm{mg} / \mathrm{ml})$. After carefully stirring, the solution is covered with $1 \mathrm{ml}$ liquid paraffin, incubated in a water bath at $37^{\circ} \mathrm{C}$ and from one side illuminated by a $100 \mathrm{~W}$ bulb placed at $10 \mathrm{~cm}$ distance. The time required for complete decolouration of the methylene blue is recorded. The enzyme activity can be calculated using the following formula $(120 /[\mathrm{T} \cdot \mathrm{H}])=\mathrm{IU}(\mathrm{T}=$ time in minutes, $\mathrm{H}=$ hemoglobin concentration of the hemolysate in $\mathrm{g} / 100 \mathrm{ml}$, 120 - empirical coefficient).

Resulls. The red cell G-6-PD activity found in 150 hematologically healthy adults are expressed in Figure 1. The mean activity is $19 \mathrm{IU}$ and the $2 \mathrm{~s}$ range 14-24 IU. In Figure 2 the values of 45 blood samples with low, normal and increased enzyme activity are plotted against the exact values found by spectrophotometric determination of the NADP reduction at a wave-length of $340 \mathrm{~nm}$. The fairly good correlation indicates, that the modified dye test is a valuable semiquantitative method for clinical purposes.

Zusammenfassung. Es wird eine weiter vereinfachte Variante des von Motulsky angegebenen Farbstofftests beschrieben, die keine besonderen Laboratoriumseinmichtungen erfordert und für klinische Zwecke ausreichend genaue semiquantitative Resultate ergibt.

H. R. MARTI

Department of Internal Medicine, Kantonsspital 5001 Aarau (Switzerland), 17 January 1968.

1. O. Tönz and K. Betke, Proc. 8th Congr. Europ. Soc. Haemat. Vienna 1961 (Karger, Basel, New York 1962), vol. 2, p. 320.

2 O. Tönz and K. Betke, Klin. Wschr. 40, 649 (1962),

3 A. G. Motulsky, J. M. Kraut, W. T. Thueme and D. F. Musto, Clin. Res. Proc. 7, 89 (1959).

4 F. Michot and H. R. Marti, Klin. Wschr. 42, 1028 (1964).

\section{CORRIGENDUM}

G. Avigad and J. Nussbaum: Marking of Chloroplast Galactolipids with Tritium, Experientia 23, fasc. 11, p. 983 (1967). On page 983, line 2 reads correctly as follows: 'EC 1.1.3.9.) acts on D-galactose, 2-D-galactosamine and', instead of 2-D-glucosamine. 